\title{
Growing Precarity, Circular Migration, and the Lockdown in India
}

\author{
Ravi Srivastava ${ }^{1}$ \\ Published online: 10 September 2020 \\ (c) Indian Society of Labour Economics 2020
}

\begin{abstract}
The paper examines the nature of the migrant crisis in India after the country-wide lockdown in March 2020 and brings out the types of labour migrants who were severely adversely affected by the lockdown, leading to their exodus towards their native villages. It further assesses the government's response and proposes some key policy imperatives.
\end{abstract}

Keywords Migrant Crisis · Circular Migration · Precarity $\cdot$ India

The COVID-19 pandemic has made the position of international migrants even more vulnerable and has exposed the poor living conditions in which international emigrant workers work and live in countries across the globe. However, in the case of India, the lockdown imposed to slow the spread of the pandemic created an unprecedented humanitarian crisis for internal migrants, revealing the vast magnitude of invisible and vulnerable migrants in India's workforce across cities and states.

In a public address to the nation on 19 March 2020, the Indian Prime Minister announced a "Janata (people's) Curfew" on March 22, from morning to night, which was to be monitored by civil society organisations, and voluntarily observed. At that stage, India had experienced 3 deaths and 169 infections due to the COVID-19. Several trains were cancelled and flights reduced for the Janata curfew, but these cancellations continued after the "curfew". On March 23, at 8 pm, the Prime Minster announced a country-wide lockdown effective from midnight, to last till 15 April 2020. The lockdown was introduced to ostensibly slowdown and break the transmission cycle of the virus, and people-except those engaged in essential serviceswere advised to stay indoors.

The sudden lockdown left tens of millions of people stranded across India. These included students, travellers, pilgrims, and migrant workers. The government and the country were completely unprepared for what followed. Within a couple of days

Ravi Srivastava

ravi.srivastava@ihdindia.org

1 Centre for Employment Studies, Institute of Human Development, Delhi, India 
of the lockdown, migrants started thronging highways and bus stands, prepared to go home anyhow. Between March 28 and 30, the government responded with a series of directives asking the migrants to return and stay indoors. When the numbers became unmanageable, some state governments stepped in with announcements to facilitate the interstate movement of the migrants. However, the central government came down heavily both on governments, which were seen to facilitate the movement of migrants, and on the migrants. The latter were forced into shelters and quarantines or pushed back to their shelters. On March 31, in response to a petition in the Supreme Court, the Government of India claimed that "not a single migrant was on the roads". It further claimed that the attempted exodus of migrants was the result of a panic created by fake news that the lockdown would continue for three months. As is well known, the Supreme Court concurred with this view and expressed satisfaction at the steps taken by the government for relief and immobilisation of the migrants.

\section{The Migrants and the Causes of the Exodus}

In its submission to the Supreme Court on March 31, the Government of India stated that India had 4.14 crore migrant workers. A perusal of the 2011 Census of India shows that this is the figure of all migrants (internal as well as international) in India who gave "employment" as the initial reason for migration whenever they had changed their Usual Place of Residence. It is clear that the government did not have any idea of the numbers or the kind of migrants who were facing distress and who were attempting to return to their homes. In the same year, the Census showed that there were 45 crore internal migrants in India, of whom 19.4 crores were workers. Most migrants in India do not give employment as a reason for migration, but rather marriages and other associational reasons (moving with families). An analysis of all the migrants in India shows that they fall into different streams and segments. Most migrants move short distances, within the same district, followed by movement to other districts within the state. Only a small percentage $(12 \%)$ of those recorded in the Census move to other states. While the classic migration in development literature is rural-urban, most migrants in India (61\%) are in rural areas. Studies show that the migrants are more likely to be concentrated in higher consumption quintiles than non-migrants. Furthermore, unlike the classical one-way rural-urban movement, a large percentage of rural-urban migrants retain their links with the rural hinterland, returning occasionally to it during spells of unemployment, for holidays, or when work in rural areas peaks. Some of them may stay on permanently in urban areas, while others may eventually return to their rural homes.

So who were the migrants who were impelled to move back to their homes in villages after the lockdown? These were clearly not the permanent rural-urban migrants who have severed links with their rural origin. They were quite prominently semi-permanent or long-term circular migrants who had retained links with their families homes in rural areas. Even more prominently, they were seasonal and short-term circular migrants who do not figure in Census and NSS statistics and who have no worthwhile place they can call their home in the urban destination areas. 
Delving a little more in the nature of short-term and long-term circular migration, studies have shown that the former are in temporary and seasonal precarious jobs, mostly in wage employment. The latter belong to various socio-economic strata but include a large chunk of precariously placed rural-urban migrants who are either self-employed or wage-employed. Unlike the short-term circular migrants, they have acquired a tenuous foothold in urban areas, although acquiring this foothold may have taken a number of years. Like the short-term circular migrant, this segment of long-term circular migrants also remains in precarious jobs, vulnerable to shocks. Estimates of these three segments of migrant workers and precarious workers among short-term and long-term circular migrant workers are given in Fig. 1 and are based on the estimates prepared in Srivastava (2020b).

Our analysis elsewhere shows the growing precarity of the Indian workforce engaged in industry and services (Srivastava 2019). While this workforce has steadily grown, but only matching the decline in the agricultural workforce, or estimates show that between 2004-2005 and 2017-2018, the percentage share of circular migrants in the precariously employed workforce outside agriculture grew by about ten per cent points-from about $47 \%$ to $57 \%$ (see Fig. 2). We have argued that precarity and circular migration have grown hand in hand, promoted by macroeconomic and labour policies in India (Srivastava 2019).

The lockdown exposed the vulnerable circular migrants to a range of extreme vulnerabilities, which were felt within a short period of time, ranging from immediate to a few days. First, the lockdown was so severe that all circular migrants, except a handful engaged in essential permitted services, lost access to jobs and incomes. Wage workers employed through contractors even lost access to wage and income

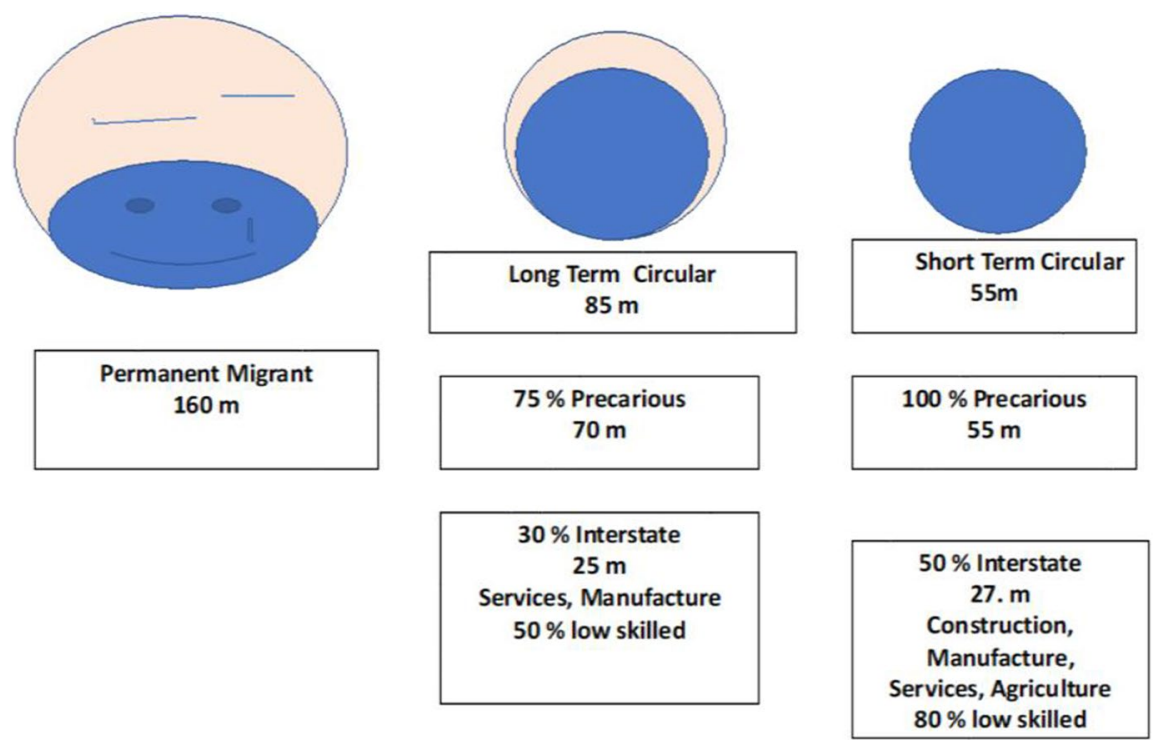

Fig. 1 Permanent, long-term and short-term circular migrants, 2017-2018. Source: Computed from Census $2001 \& 2011$, and NSO, 2007-2008 \& 2011-2012 


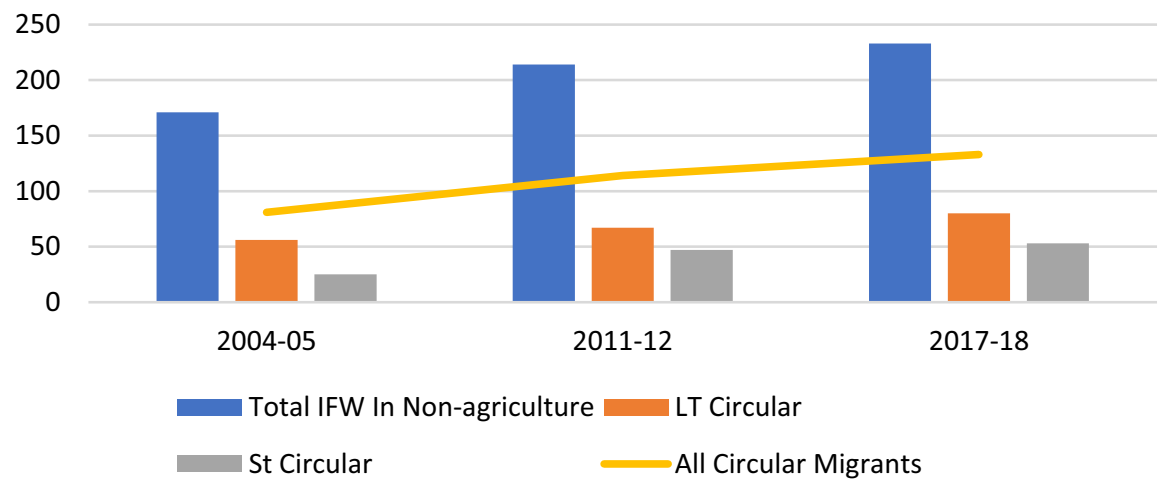

Fig. 2 Circular migration \& informal employment, 2004-2005, 2011-2012, \& 2017-2018. Source: Computed from Census 2001 \& 2011, and NSO, 2007-2008 \& 2011-2012

arrears, as contractors refused to settle dues. Second, those circular migrants—and these included a majority of the short-term circular migrants-lost access to shelters which were nothing but their worksites. Those who lived in squalid and congested rented accommodation were left with no means to pay rent and started to be pressurised by their landlords within the first few weeks. Third, as we show below, government measures for social protection were least likely to reach these workers as few of them had valid registrations in the destination areas, and relief was both scarce and difficult to access. Fourth, the distance from kin and family folk was acutely felt by the risk of disease, and government barriers on interstate movement made going back all the more urgent for interstate migrant workers and their families.

\section{Initial Support Measures by the Government of India}

The Government of India announced a package of measures to support poor households and workers on March 25, immediately after the imposition of the lockdown. This package was called the Prime Minister Garib Kalyan Yojana and it comprised of measures of cash transfer using the Direct Benefit Transfer (DBT) route, kind support (through the Public Distribution System), and a set of directions to various Statutory Funds/Welfare Funds, and finally a set of directives whose legal backing, if any was derived from the powers that the government derived from the Disaster Management Act, 2005 (DM Act).

The cash transfers comprised of (a) a fast forwarding of the first instalment of the income transfer scheme for farmers under the PM Kisan Yojana; (b) a cash transfer of Rs. 500 each per month for three months to woman account holders of Jan Dhan Yojana bank accounts; and (c) an amount of Rs. 1000 to each pension holder under the National Social Assistance Programme. As kind assistance, the government offered extra free rations of $5 \mathrm{~kg}$. of cereals and one $\mathrm{kg}$. pulses per person for three months and a provision of free gas cylinders under the Ujjwala scheme. The government also involved the Employee Fund Organisation (EPFO) and the State Welfare 
Funds under the Building and Construction Workers' Welfare Fund by asking the former to give concessions to workers and employers, and the latter to make ex gratia payments to construction workers. Finally, it also issued a directive to employers to pay wages to workers during the lockdown period and asked landlords to exempt workers from payment of rents during that period and increased the wages payable under MGNREGA from Rs. 182 to Rs. 202.

Although the total package carried a price tag of Rs. 1.7 lakh crores, the additional cost to the government exchequer was Rs. 87,000 crores, or only about $0.4 \%$ of GDP. More important, while the meagre assistance amounts were targeted at existing beneficiaries, they could not touch the circular migrants who did not have access to the PDS in destination areas, and many did not even have access to bank accounts, leave alone beneficiary accounts. Similarly, the directions to pay wages during lockdown and rent remissions by landlords had no practical impact on the migrant workers engaged in informal jobs. In general, as surveys of migrant workers succeeded in bringing out, the limited package announced by the government bypassed most of the circular migrants, exacerbating their condition in the cities.

\section{The Exodus}

Despite the stiff conditions of the lockdown, large number of migrants made it to their homes just before or after the lockdown was announced, but these were mostly intra-state migrants. The government's strict measures stemmed the tide of the exodus which had started soon after the lockdown. But after the announcement of the second lockdown on April 15, the exodus turned into a tide, with workers and their family members attempting to walk back across thousands of kilometres, even in the face of harassment and worse by government forces. The government of India's policy response continued to treat the movement of the migrants simply as a violation of the lockdown procedures. There was very little acknowledgement of the difficult conditions of the migrant workers and their families. The policy measures that were announced were contradictory and aimed at continued restriction on coordinated interstate movement of migrants. Initially, the central government announced (on April 19) permission to deploy migrant workers within destination states where they were stranded. Then, on April 29, it permitted interstate movement, subject to protocols but only by buses. On May 1, trains were permitted to be deployed but through a cumbersome administrative and interstate coordination procedure, and on May 3, the central government again issued a notification virtually disentitling temporary migrants from interstate movement.

But since mid-April, for the next several weeks, the country saw the largest urban exodus ever in its history, with millions of migrants attempting to move back to their home villages on foot, bicycles, cycle carts, and hired vehicles. By the beginning of June, the government estimated that it had been able to facilitate the interstate movement of about a crore of migrants, but several times that number moved on their own under unimaginable conditions. Migrants bore significant costs, financial and nonfinancial, both for their autonomous movement, but also the transportation arranged by the States and the Railways, with them or their families incurring debts to make 
this possible. As is well known, several hundred people died in the process, including more than a hundred on trains.

\section{Follow-Up Measures Taken by Central and State Governments}

Since May 2020, the Government of India has announced some follow-up measures to support the affected poor and the migrant workers. Under the Atma-Nirbhar Package that was elaborated by the Finance Minister between May 20 and 25 May 2020, the Government enhanced the MGNREGA budget by Rs. 40,000 crores. It announced a scheme worth Rs 3,500 crores by which States could identify and provide free ration $(5 \mathrm{~kg}$. per month of cereals and one $\mathrm{kg}$. pulses per month for three months) to each migrant workers and her/his family member not covered under the National Food Security Act (NFSA). It also announced concessions through the Employees Provident Fund Organisation to employers and workers in some categories. It declared a scheme to provide working capital to street vendors to provide support to a rental housing scheme with an initial outlay of Rs. 600 crores.

On June 20, the Prime Minister announced the Prime Minister Garib Rojgar Abhiyan in 116 districts in six states, with more than 25,000 returnees migrant each as per the government data. Under the scheme, the implementation of 25 existing schemes/works, costing about Rs. 50,000 crores (without any additional financial allocation), was to be frontloaded in these districts in order to provide employment.

On June 30, the Prime Minister announced the extension of the free gas cylinder and PDS ration schemes for another four months (till November 2020) at an estimated budgetary cost of Rs. 76,000 crores.

Taken together with the earlier measures announced in March, the total budgetary outlay on the measures announced is only about $1 \%$ of GDP. In addition, the central several non-budgetary measures also include portability of PDS by June 2021.

Meanwhile, most states were highly ambivalent in their policies towards sending/ receiving migrants for different reasons. States initially responded with tightening the controls on migrant movement and arranging shelter/quarantines and food for them. Kerala, by standards of destination states, does not account for a significant percentage of circular migrants, set up the largest proportion of shelters.

A number of state governments announced ex gratia payments from the Building $\&$ Construction Welfare Funds for workers registered under these funds. However, in most states, interstate migrant workers are not registered and among those workers, are a high proportion of those who are not employed in the construction industry. We must note that Kerala emerged as an outlier among states by announcing a comprehensive package of Rs. 20,000 crore for protection of livelihoods of workers, including migrant workers, even before the lockdown.

Apart from these ex gratia payments, some states followed up with other ex gratia payments and made additional efforts to provide rations to workers, including migrant workers, not registered in the PDS. Telangana announced an ex gratia payment for migrant workers early on in the second phase of the lockdown, as did Kerala. As the migrant crisis escalated, sending states announced measures to support 
stranded migrant workers. In the beginning, an initiative was taken by Jharkhand, followed by Bihar which announced an ex gratia payment of Rs. 1000 per worker.

With the return of the migrants, state governments have announced measures for preparing a database of migrants and their skills, and programme to absorb them in the local economies. The Odisha government announced a Rs. 17,000 package to provide support to the MSME and rural sectors, and skill training, with the objective of enhancing employment opportunities to migrant returnees.

These measures have provided a patchwork of support to migrant workers and their families. At the same time, several state governments have moved ahead to make drastic changes in labour laws, in some cases (as in Uttar Pradesh and Gujarat) almost abolishing the entire framework of labour regulation and social security under the flawed assumption that this will help to revive investment and economic activity.

\section{Current Policy Imperatives}

The pandemic and the lockdown have brought to light the extent to which industrial and urban India has grown to depend on the labour of migrant workers. At the same time, it has also exposed the precarity and vulnerability of these workers, in terms of their jobs and employment relations, their living conditions, and lack of social protection. With the passage of time, and as the economy slowly begins to revive, the gap in wages and employment opportunities can be expected to draw many of the migrants back into migration circuits and urban destinations. The moot question is whether the lessons of the crisis during the pandemic are addressed by the state in the short and medium period.

The pandemic has given several other clear lessons which are unaddressed in the policies taken by the Indian state so far.

First, it is undeniable that the migrants claim to constitution rights vis a vis Articles 14, 15, 17, and 19 of the Constitution as citizens have not been respected, either in the destinations where they work or in their areas of origin. Given the integral link between migration and development, there is a need to reflect and strengthen their full rights as citizens.

Second, the pandemic has again brought home the important fact that public health is an externality and that state and employers need to invest more in workers' health.

This also means much higher investment in workers' housing and access to basic amenities.

Third, the grim situation of the migrant workers reinforces the need to institute an adequate social protection floor for all the workers. There has been an urgent immediate requirement for income transfer for a few months to compensate informal workers for their loss of income during the lockdown. On behalf of the Indian Society of Labour Economics (ISLE), a large number of economists and public figures had demanded a short-term quasi-universal income transfer of Rs. 6000 to households. In the short to medium term, there is a need to institute universal social security for all workers, including the migrants who are informal workers. The Code on 
Social Security presented to Parliament in 2019 does not present a time bound road map for universal social security.

Fourth, in the interim, there is need to institute portability in existing social protection schemes, some of which have statutory backing and Central funding (Srivastava 2020a). Portability and a universal social security system will require a panIndia system of social security registration, which can guarantee privacy, security, and safety of the registrant's information.

Fifth, the devastating circumstances of the migrants remind us that the labour market needs to be re-unified with registration and formalisation of the workforce and greater job security being provided for informal workers, including the circular migrants. This would also mean a thorough review of the Labour Code on Occupational Safety, Health, and Working Conditions which currently promotes informality, with inadequate provisions for occupational safety and health. This also demands a reversal of the direction of labour law changes which several states have undertaken in the name of increasing the ease of doing business.

Sixth, the situation requires an institution of an integrated rural-urban and regional planning framework, which can promote rural regeneration, especially in poorer states, on the one hand, and inclusive urbanisation, on the other.

In conclusion, the pandemic should provide an opportunity to gear the economy towards more equitable and inclusive development rather than increased inequalities built on the higher precarity of informal workers in general, and circular migrants in particular.

\section{References}

Srivastava, Ravi. (2020a). Vulnerable internal migrants in India and portability of social security and entitlements. Centre for Employment Studies Working Paper Series. WP02/2020, New Delhi: Institute for Human Development.

Srivastava, Ravi. (2020b). Understanding circular migration in India: Its nature and dimensions, the crisis under lockdown and the response of the State. Centre for Employment Studies Working Paper Series. WP04/2020, Institute for Human Development, New Delhi.

Srivastava, Ravi. 2019. Emerging dynamics of labour market inequality in India: Migration, informality, segmentation and social discrimination. The Indian Journal of Labour Economics. https://doi. org/10.1007/s41027-019-00178-5.

Publisher's Note Springer Nature remains neutral with regard to jurisdictional claims in published maps and institutional affiliations. 